\title{
CARDigues: an integrated tool for levee system diagnosis and assess-
}

\section{ment}

\section{E. Durand}

Cerema, Direction territoriale Normandie-Centrel LR Blois, 11 rue Laplace - CS 32912 - 41029 Blois Cedex, France

\section{J. Maurin \& B. Bridoux}

DREAL Centre - Val de Loire, 5 avenue Buffon-CS96407, 45064 Orléans cedex 2, France

\section{A. Boulay}

Direction Départementale des Territoires du Loiret, Cité administrative Coligny, 131 faubourg Bannier, 45000 Orléans, France

ABSTRACT: In December 2007, a French decree related to hydraulic structures (levees and dams) has introduced for owners the necessity to produce a hazard study for each levee system. On the river Loire, three major class $\mathrm{A}^{*}$ state levee systems are present and protect three main urban areas, Orléans, Tours and Authion representing some 240000 inhabitants. Around 40 class $\mathrm{B}^{*}$ and $\mathrm{C}^{*}$ levee systems are also present on the river Loire and its tributaries representing $600 \mathrm{~km}$ of levees and requiring such hazard studies. In order to have a homogenous method to do these specific risk assessment studies on river Loire levees, a new model named CARDigues (for Levee Breach Hazard Calculation) was developed in a partnership with DREAL Centre-Val de Loire, Cerema and Irstea. This model enables to approach the probability of failure on every levee sections and to integrate and cross different "stability" parameters (topography, embedded structures, geology), hydraulic solicitations and observations from visual inspections or instrumentation results considered as disorders (seepage, burrowing animals, vegetation, pipes, etc.). This model and integrated tool CARDigues enables to check for each levee section, the probability of appearance and rupture of five breaching scenarios initiated by: overflowing, internal erosion, slope instability, external erosion and uplift. It has been recently updated and has been applied on several levee systems by different contractors. The article presents the CARDigues model (V28.00) with examples on river Loire and how it is currently used for a relevant and global levee system diagnosis and assessment. Levee reinforcement or improvement management is also a perspective of applications for this model CARDigues. (* levee classes are function of levee height and protected population)

\section{INTRODUCTION}

The aims of levee hazard studies are to point out critical segments of levee protection system and to estimate breach probability under different flood events. For Loire levees a hazard study had to be done on 40 levee systems (600 levee kilometers) between 2008 and 2014.

Therefore, a technical committee of Loire levees hazard studies was created with DREAL Centre (owner of levee systems), Irstea and Cerema, two specialized state contractors. Then in 2008, a specific and semi-probabilistic methodology for class $A^{*}$ levee breach hazard calculation was established (Durand, 2012) and Cerema developed the dedicated tool named CARDigues. This model which is developed under "Excel" can take simultaneously into account several parameters such as geometry of the levee, geology, geotechnical characteristics of the levee and its foundation but also some parameters coming from technical and visual inspections or extracted from a specific levee database named SIRSDigues or some parameters due to reinforce- ments or other security barriers coming from management operations.

\section{GLOBAL CONCEPT}

\subsection{Levee system discretization}

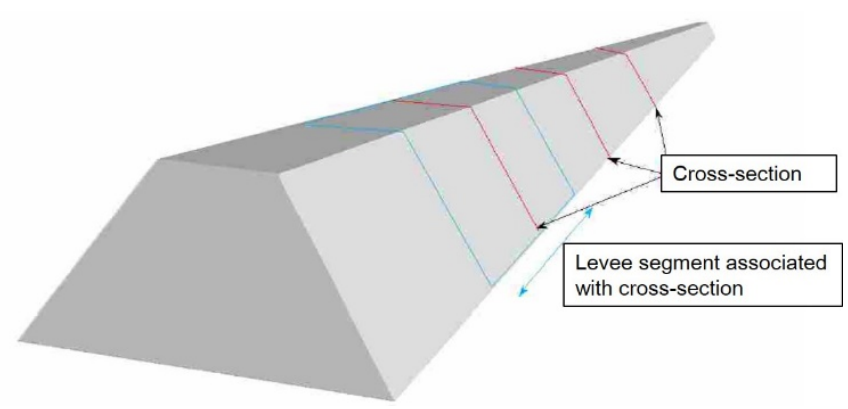

Figure 1. Description of the levee system discretization in representative levee segments (after Maurin J. et al. 2013)

In the CARDigues methodology, the levee system is divided in 50 meters long segments (Fig. 1). Each segment is represented by a levee cross-section representing the more critical statement of the levee along this segment. Cross-sections were established 
with Lidar survey and locally field measurements. A high resolution Lidar Flimap was also tested for Orléans levee system.

For example, the 3 main river Loire levee systems were divided into 877 (Orléans), 1166 (Tours) and 1593 (Authion) segments. For Blois, the class B* levee system of the left bank was divided into 517 segments.

\subsection{Probability calculations principles}

On each cross-section, breach hazard is calculated for the 5 main failure modes identified on river Loire i.e.: overflowing (s), internal erosion (ei), slope instability $(\mathrm{g})$, external erosion (ee) or scour at the river side levee toe and uplift (sh). These failure modes can be described as levee failure scenarios. Then in CARDigues model, 5 different failure scenarios are distinguished and named by their elementary initiation mechanisms but bring into play more often several elementary mechanisms.

For each flood event Qi, levee breach probability calculations are divided in two parts: the probability of appearance of the initiating phenomena $\mathrm{P}(\mathrm{na})$ and in second time the levee breach probability initiated by this phenomena, $\mathrm{P}(\mathrm{nr})$. Then, the levee breach hazard $\mathrm{P}(\mathrm{n}) \mathrm{Qi}$ (or factual probability) initiated by this phenomena (n) is the combination of both former probabilities:

$$
\mathrm{P}(\mathrm{n})_{\mathrm{Qi}}=\mathrm{P}(\mathrm{na}) \times \mathrm{P}(\mathrm{nr})
$$

Two other probabilities are also defined and calculate for each cross section: The "global breach hazard" $\left(\mathrm{P}_{\text {rupture }}\right)_{\mathrm{Q}}$ also called the "all modes factual probability" and the "annual breach hazard" $\mathrm{P}(\mathrm{n})_{\text {an }}$ also called "annual failure probability". These probabilities are given by:

$$
\begin{aligned}
&\left(\mathrm{P}_{\text {rupture }}\right)_{\mathrm{Qi}}=[1-((1-\mathrm{P}(\mathrm{s})) \times(1-\mathrm{P}(\mathrm{ei})) \mathrm{x} \\
&(1-\mathrm{P}(\mathrm{ee})) \times(1-\mathrm{P}(\mathrm{g})) \times(1-\mathrm{P}(\mathrm{sh})))
\end{aligned}
$$

Or

$$
\left.\left(\mathrm{P}_{\text {rupture }}\right)_{\mathrm{Qi}}=\operatorname{MAX}[\mathrm{P}(\mathrm{s}) ; \mathrm{P}(\mathrm{ei})) ; \mathrm{P}(\mathrm{ee}) ; \mathrm{P}(\mathrm{g}) ; \mathrm{P}(\mathrm{sh})\right]
$$

And

$$
\mathrm{P}(\mathrm{n})_{\mathrm{an}}=\sum_{i=50}^{\infty} \mathrm{P}(\mathrm{n}) \times \mathrm{P}(\mathrm{Qi})
$$

where $\mathrm{P}(\mathrm{Qi})$ is the annual probability that the flood event of return period Qi occurs (with Q representative of an interval $[\mathrm{a}, \mathrm{b}]$ where $\mathrm{Qa}<\mathrm{Qi}<\mathrm{Qb}$ as shown on Fig. 2).

For each cross-section two probabilities are calculated for each flooding situation, for each failure modes and finally for all failure modes.

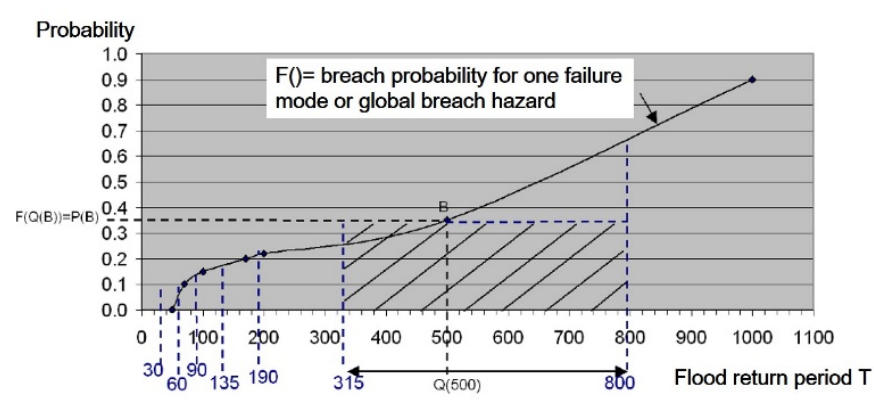

Figure 2. Graphic showing the principle of probabilistic space discretization used in CARDigues (after Durand E. 2015)

\section{ENTRANCE DATA OF THE MODEL}

\subsection{General data}

Each cross-section is localized with a number, its kilometric point $(\mathrm{Pk})$ from the origin of the levee system. Parish and locality names where stand the cross-section, owner and stakeholder names, number identification from managing database are entered in the tool in order to make the links with former und future studies.

\subsection{Topographic data}

Each cross-section is defined with $\mathrm{X}, \mathrm{Y}$ and $\mathrm{Z}$ coordinates of seven characteristic points (defined on Fig. 3). Geotechnical stratigraphic data enable to complete the profile with the positions of the roof of each layers and substratum. The cross-section is then represented by a simplified geometric figure.

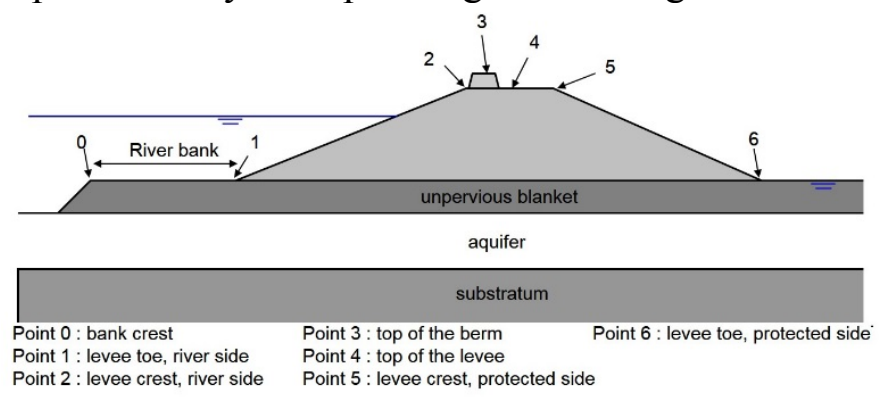

Figure 3. Characteristic points of a levee profile in CARDigues model (courtesy Durand E.)

The point 4 is considered as the top of the levee and defines the levee system crest polyline. Coordinates are set in official reference system: Lambert 93 for $\mathrm{X}$ and $\mathrm{Y}$ and NGF (IGN69) for Z. This topographic data enables to calculate automatically several geometric characteristics such: levee width at the toe and crest, levee height, slopes, riverbank width etc.

\subsection{Hydraulic data}

CARDigues V28.00 can take into account for each cross-section 8 river flood levels given by hydraulic calculations. A hydraulic free level at the protected 
side of the levee can also be integrated to simulate a former inundation or the presence of water in protected area.

\subsection{Geotechnical data}

Regarding the global composition of Loire levees all along the river Loire and geotechnical characteristics of materials, a constant "medium levee composition" had been retained. The levee core is then assimilated to a silty sand $\left(c^{\prime}=5 \mathrm{kPa} ; \Phi^{\prime}=30^{\circ}\right.$ and $\rho d=18$ $\mathrm{KN} / \mathrm{m} 3$ ) and entered in CARDigues model. Levee foundation is described (Fig. 2) as a 3 geological homogenous strata. Successively: 1/ a fine soil (silt or clay) with a low permeability; 2/ an alluvial coarser pervious strata (sand or coarse sand or gravel) 3 / an impervious substratum.

\subsection{Structural data and disorders}

This kind of information have an influence on probability calculations. They depend on levee utilization, occupation and disorders present on levee such as : presence and type of berm (earthen, masonry wall) on the top of the river or protected side of the levee, embedded structures (house, retaining wall); low points on levee crest; arborescent vegetation and its density (full cover; medium cover or punctual); crossing pipes and its elevation (low, medium, high or its elevation Z); animal burrows (crossing the levee or not); disorders on protected levee slope (obstacles, erosion of grass cover or both); aggravating factors such as scour, obstacles); other aggravating factors of internal erosion.

\subsection{Reinforcement, protection or amelioration data}

The positive factors that increase the levee stability and the levee safety are also integrated in the model. Following elements are taking into account in calculation: presence of a spillway or a segment design for and resistant to overflowing; slope protections on protected side of the levee, cut-off wall; scour protections on river side; other factors that fight against internal erosion.

\subsection{Management data}

The ability of manager to anticipate or repair a deterioration or failure of a levee component can be taken into account. Three cases are distinguished for these secondary factors:

- the operator is able to inspect the levee and to intervene in case of deterioration before the flood event;

- the operator is able to inspect the levee and can intervene in case of deterioration during the flood event;

- the operator is not able to inspect the levee and then to intervene in case of deterioration (its notably the case when people safety can't be assumed during exceptional flood event because inspectors must be evacuated);

\section{BREACHING PROCESSESS AND FAILURE MECANISMS}

CARDigues takes into account the five main failure modes that occurred historically on river Loire levees (Cemagref, 2001). They are named by the mechanism that initiate the failure mode and which, combined to each other's, can lead to a breach. Mechanisms are:

\subsection{Overflowing}

The overflowing happens when the river level becomes higher that the elevation of the top of the levee (point 4 on Fig. 3). The flow passes over the crest and erodes the material on the protected side levee slope. This mechanism accelerates itself when slope gets steeper and/or when flow gets concentrated (or perturbed). This scenario often leads to a levee breach. It's slow down with the quality of grass slope revetment, the presence of a protection and the gentleness of the slope.

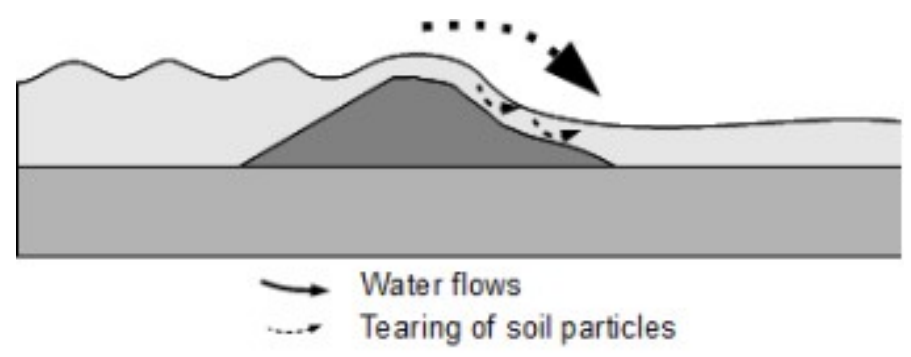

Figure 4. Principle of erosion by overflowing process (ILH 2013, Courtesy Y. Deniaud)

\subsection{Internal erosion}

"Internal erosion" is a general appellation to qualify phenomenon where material particles are dragged away by an internal flow. Currently four mechanisms are considered: backward erosion, concentrated erosion, contact erosion and suffusion (Fig. 5). 

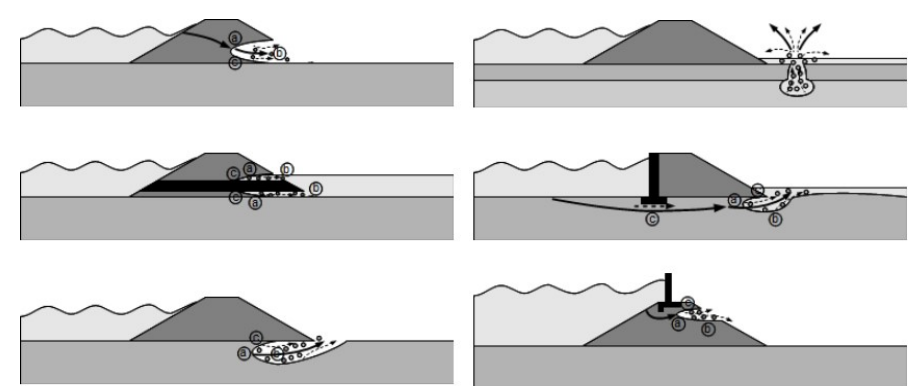

$\rightarrow$ Water flows

$\longrightarrow$ Tearing of soil particles

(a-backward erosion, b- concentrated erosion, $c$ - contact erosion)

Figure 5. Examples of internal erosion processes and localizations in the levee or its foundation (ILH 2013, Courtesy Y. Deniaud)

Two conditions must be fulfilled to initiate internal erosion: the water must flow through the levee core and/or its foundation and particles must have the possibility to be dragged away from material network to the downstream side of the levee.

This phenomenon could accelerate itself when permeability or gradient increase but it can also get stopped if drainage or filtration occurred. For levees, internal erosion is the second cause of breaching process after overflow. It is also often combined with other mechanisms and can constitute the last mechanism that leads to a levee breach.

In CARDigues methodology, backward erosion (trough or under levee) is considered and its initiation is facilitated by factors such as: animal burrows, tree roots, crossing pipes and the combination of this factors.

\subsection{Slope instability}

Slope instabilities are mass instabilities. Horizontal slidings can occur but rotational slidings are mostly observed in earthen levees. This mechanism generally occurs on the protected slope of the levee during flood event but can also occur on the river slope, during drawdown (Fig. 6).
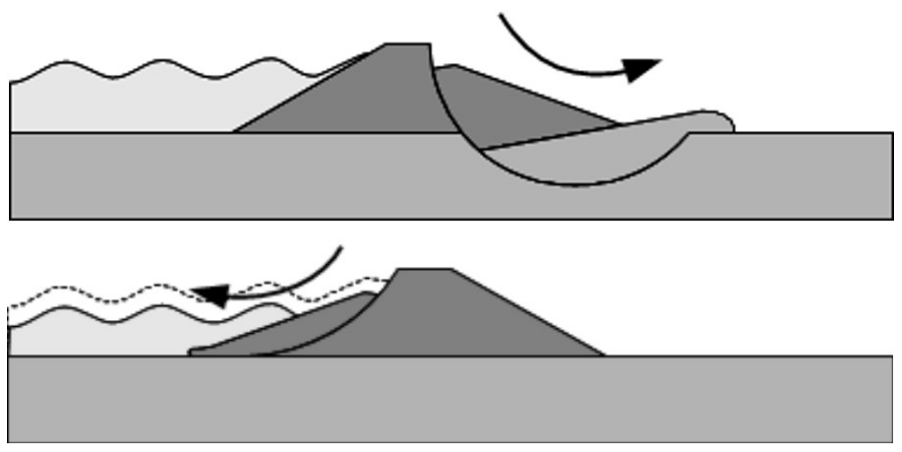

Figure 6. Examples of rotational slope slidings (after ILH 2013, Courtesy Y. Deniaud)

Slope sliding mechanism do not lead directly to a levee breach. It can initiate other mechanisms such internal erosion (because of the levee width reduc- tion induced by mass sliding). This scenario is taken into account in CARDigues.

\subsection{External erosion and scour}

In CARDigues methodology, external erosion is scour phenomenon. It occurs when river flow erodes levee toe material or its foundation. Erosion of material on the levee slopes is also external erosion only the first case leads to breach directly in case of overflow (see §4.1). For other cases, external erosion initiates a slope instability and, combined to internal erosion, can lead to the levee breach. This mechanism is affected by aggravating factors (presence of an obstacle at the river toe, preexisting scour ditch) and can be limited with positive factors (presence of reinforcements at the river levee toe). These factors are taken into account in CARDigues.

\subsection{Uplift}

This phenomenon corresponds to a destabilization process of the protected slope of the levee due to an exceedance of under pressures in the aquifer localized below an impervious layer (Fig. 7).

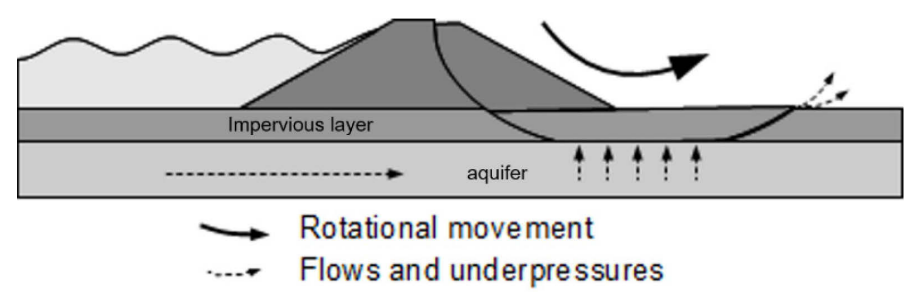

Figure 7. Principle of a slope sliding caused by uplift (ILH 2013, Courtesy Y. Deniaud)

In case of high hydrostatic pressures in aquifer, cracks can appear in impervious layer (silt or clay). Flow can then appear and backward erosion can be initiated, deformations induced and a decrease of shear strength lead to slope instability. In CARDigues methodology, uplift can't lead to a levee breach by itself but can initiate internal erosion and thereby lead to breach.

\subsection{Other breaching processes not take into account}

General instability of levees had never been observed on river Loire levees. Therefore, this mechanism is not treated in CARDigues. Despite the fact it is still frequently observed along the river Loire, the breaching process due to a karstic activity underneath the levee had not been taken into account. The knowledge of this complex phenomenon is currently too poor. That's why some dedicated research projects were recently submitted. 


\section{PROBABILITY CALCULATIONS}

\subsection{Hypothesis}

For probabilistic calculations, events that are combined need to be independents. CARDigues model is based on this hypothesis but it's an evidence that levee segments breach probabilities are interdependents. Indeed, when a breach occurs on a segment, the neighbor segments are then dragged in the breach and the far from segments would have a minor breach probability induced by hydraulic head reduction provoked by the breach.

Nevertheless, the aim of hazard studies is to estimate the probability of the first breach of the levee system. Thus we considered that probabilities are independents as long as a breach doesn't occur. Therefore, CARDigues model can be used to identify, by relative comparisons, cross-sections were the levee breach failure probabilities are the highest, i.e. cross-sections where breach has the highest chance to occur.

Principles of probability calculations are described in $\S 2.1$ for each failure mode. This complex methodology is based for each failure mode on a logical chart to take into account the most realistic scenarios. Principles of this methodology is described hereunder for each of the 5 mains failure modes.

\subsection{Overflowing}

The overflow appearance probability depends on:

- the freeboard, i.e. the difference between considered hydraulic level and levee top elevation (point 4 on Fig. 2). It can be positive or negative,

- the presence of a berm on levee crest an its defined efficient height (on flow),

- a height of uncertainties defined to take into account all topographic and hydraulic uncertainties.

The overflow breach probability, when the phenomenon is occurred depends on the overflowing height. Regarding historical events (Piney S. 2011), it is considered that the probability is equal to unit when overflowing height is greater than $0,20 \mathrm{~m}$. Some specific calculations and probabilities are affected to take into account: spillways or overflow resistant segments (where probability is $10^{-3}$ ), berm on protected side of levee crest (case with a breach probability of 1 because of the concentration effect of flow on slope).

Some secondary coefficients $\mathrm{Ci}$ are also used to weight breach probability. It's the case for levee slope on protected side, for width of the levee (C1 values on Fig. 8), for obstacle presence on slope, erosion signs or water height on the protected toe of the levee.

\begin{tabular}{|c|c|}
\hline Width of the levee crest & Coefficient $C_{1}$ \\
\hline $0 m<L<30 m$ & 1 \\
\hline $30 m<L<40 m$ & 0.8 \\
\hline $40 m<L<50 m$ & 0.5 \\
\hline $50 m<L<100 m$ & 0.1 \\
\hline $100 m<L$ & 0.01 \\
\hline
\end{tabular}

Figure 8. Example of overflow breach probability weighting coefficient function of levee width (after Durand E. 2015).

\subsection{Internal erosion}

The internal erosion appearance probability is defined with the average gradient method of Bligh based on the raw ratio $c=L / \Delta H$ (where $L$ is the levee width at its base and $\Delta \mathrm{H}$ the hydraulic head). A probability is associate in function of intervals of $\mathrm{c}$ as shown in Figure 9.

This simplify approach is moderated in CARDigues model (Maurin J. 2011) to take into account typical flood hygrogram, presence of disorders on levees or singularities that modify résistance to internal erosion, specific coefficients (Fig. 10) are applied on levee width L for 3 Loire levees characteristic geotechnical profiles: F1 (unreinforced profile), F2 (profile with reinforcement on river side) and F3 (profile with reinforcement on protected side).

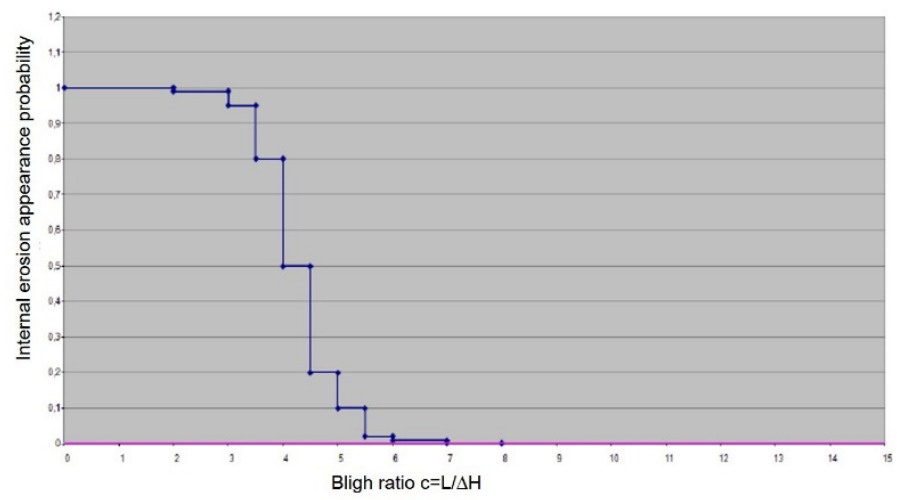

Figure 9. Internal erosion appearance probability function of Bligh ratio (from Durand E. 2015).

\begin{tabular}{|l|c|c|c|}
\hline \multirow{2}{*}{ Coefficient applied on raw Bligh ratio } & \multicolumn{3}{|c|}{ coefficients } \\
\cline { 2 - 5 } & $\begin{array}{c}\text { F1 : Digue } \\
\text { non } \\
\text { renforcée }\end{array}$ & $\begin{array}{c}\text { F2 : Digue } \\
\text { renforcée } \\
\text { côté Loire }\end{array}$ & $\begin{array}{c}\text { F3 : Digue } \\
\text { renforcée } \\
\text { côté Val }\end{array}$ \\
\hline Profil de base & 1 & 1 & 1 \\
\hline Présence de Maison encastrée Côté Val & 0.95 & 0.95 & 1 \\
\hline Présence de Maison encastrée Côté Loire & 0.95 & 1 & 0.95 \\
\hline Présence de Maison encastrée des deux cotés & 0.90 & 1 & 1 \\
\hline Présence de terriers non traversant -position haute & 0.69 & 0.67 & 0.73 \\
\hline Présence de terriers non traversant - position moyenne & 0.31 & 0.36 & 0.40 \\
\hline Présence de terriers non traversant - position basse & 0.19 & 0.27 & 0.29 \\
\hline Présence de terriers non traversant en position haute & 0.70 & 0.90 & 0.90 \\
\hline Présence de terriers non traversant en position moyenne & 0.95 & 0.95 & 0.95 \\
\hline Présence de terriers non traversant en position basse & 0.71 & 0.94 & 0.86 \\
\hline Présence de terriers traversant & 0 & 0 & 0 \\
\hline Végétation ligneuse isolée & 0.95 & 0.95 & 0.95 \\
\hline Végétation ligneuse clairsemée & 0.68 & 0.9 & 0.89 \\
\hline Végétation ligneuse généralisée & 0.34 & 0.6 & 0.65 \\
\hline Absence d'horizon argilo-limoneux en couche d'assise & 0.56 & 0.80 & 0.78 \\
\hline Présence d'une paroi étanche & 10000 & 10000 & 10000 \\
\hline
\end{tabular}

Figure 10. Table of coefficients applied on Bligh raw ratio (after Durand E. 2015). 
The internal erosion breach probability, when the phenomenon is occurred depends on the presence of drainage and filtering system and secondary on manager surveillance and organization (cf. § 3.7).

\subsection{Slope instability}

The slope sliding appearance probability is appreciated for each cross section by a factor of safety $\mathrm{F}$ (Durand E. 2015). F is obtained with parametric calculation at Ultimate Limit States based on CFBR (2010) recommendations. $F$ is obtained with Bishop method and is function of levee geometry, material characteristics and hydraulic load. Appearance probabilities are the defined according to $\mathrm{F}$ intervals. The greater is $\mathrm{F}$, the smaller is the probability of slope sliding appearance (Fig. 11).

Some specific reinforcements make the $\mathrm{F}$ greater. For example, if a rock berm is present at the river side levee toe, the factor $\mathrm{F}$ is majored by $20 \%$. For following specific cases, the probabilities are fixed to 0 in CARDigues: for embedded houses, for retaining walls, for levee slope smaller than $10^{\circ}$ or for a levee height smaller than $1 \mathrm{~m}$.

\begin{tabular}{|c|c|c|c|c|c|}
\hline \multicolumn{6}{|c|}{ Sliding appearance probability function of $\mathrm{F}$ ranges } \\
\hline \multirow{5}{*}{ Factor of safety $F$} & 0 & $\mathrm{~F}<$ & 1 & $\longrightarrow$ & 1 \\
\hline & 1 & $<\mathrm{F}<$ & 1.1 & $\rightarrow$ & 0.7 \\
\hline & 1.1 & $<\mathrm{F}<$ & 1.3 & & 0.3 \\
\hline & 1.3 & $<\mathrm{F}<$ & 1.5 & $\longrightarrow$ & 0.1 \\
\hline & 1.5 & $<F$ & & $\longrightarrow$ & 0.01 \\
\hline \multicolumn{6}{|c|}{ Probability in case of Embedded houses, retaining walls or low slopes } \\
\hline
\end{tabular}

Figure 11. Sliding appearance probability function of factor of safety ranges (after Durand E. 2015).

A slope sliding provokes a change in levee geometry and therefore increases the internal erosion probability of breach. The slope sliding breach probability $\mathrm{P}\left(\mathrm{g}_{\mathrm{r}}\right)$ is consequently defined in CARDigues with internal erosion hazard that is raised to take into account slope sliding. Two ways of augmentation are offered in the tool: with a coefficient $\mathrm{C}=1,1$ applied on internal erosion hazard $\mathrm{P}(\mathrm{ei})$ or with an over-ranking of probabilities associated to internal erosion appearance probabilities $\mathrm{P}\left(\mathrm{ei}_{\mathrm{a}}\right)$ (Fig.12).

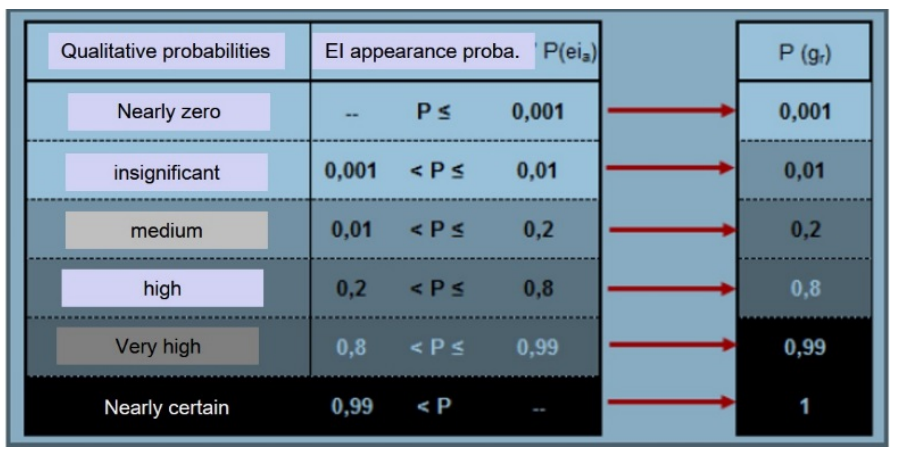

Figure 12. Slope sliding breach probabilities based on internal erosion appearance probabilities over-ranking (after Durand E. 2015).

\subsection{External erosion and scour}

In the model, scour is the unique external erosion mechanism taken into account. Indeed, no case of external erosion of river side levee slope had been observed on Loire levees and protected levee slope erosion is treated in overflowing failure mode. It's considered that scour can't lead to breach by itself. It leads to a destabilization of levee toe, causes a slope sliding and finally increases internal erosion process that can lead to a breach.

In CARDigues, the external erosion appearance probability depends on the width of river bank. The less width is the river bank, the more is the probability of (harmful) scour appearance. The model can take into account aggravating factors (existing scour ditch, obstacles and hard point at the levee toe) but also favorable factors (existing reinforcement such rocks berm or sheet piles, soft protections and other scour protections). The external erosion breach probability, when the scour phenomenon is occurred depends on slope sliding breach probability increased with a fixed multiplying coefficient of 4 .

\subsection{Uplift}

The uplift appearance probability is appreciated for each cross section by a factor of safety $F_{h}$ based on USACE (1986) method for seepage analysis and control. This factor is a function of several parameters (Fig. 13) such as alluvial and blanket thicknesses and permeability, levee geometry etc.

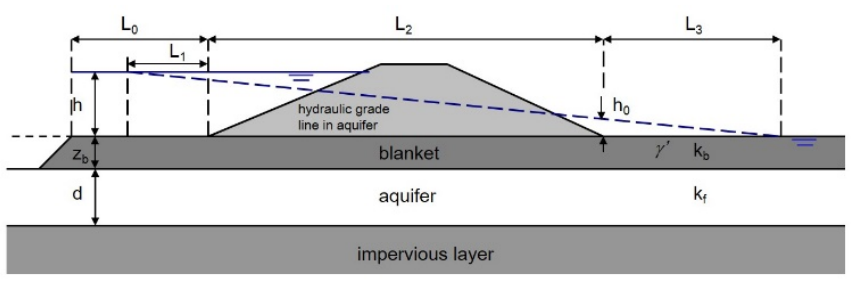

Figure 13. Cross-section and notations used for uplift security factor calculation (after USACE 1986 \& Durand E. 2015). 
The factor of safety against uplift at the downstream toe of the levee is given by:

$\mathrm{F}_{\mathrm{h}}=\frac{h o}{h c}=\frac{Z_{b d}}{h} \frac{\gamma^{\prime}}{\gamma_{\omega}} \frac{L_{1}+L_{2}+L_{3}}{L_{3}}$

where $Z_{b d}(m)$ is the thickness of the downstream blanket, hc (m) the critical pressure head, ho the pressure head under the blanket at the downstream toe, $\mathrm{L}_{1}, \mathrm{~L}_{2}, \mathrm{~L}_{3},(\mathrm{~m})$ have to be defined as:

$\mathrm{L}_{1}=\sqrt{\frac{k_{f}}{k_{b u}} Z_{b u}{ }^{d}}$

where $\mathrm{d}$ is the thickness of aquifer, $\mathrm{k}_{\mathrm{f}}$ is the horizontal permeability of the pervious foundation $(\mathrm{m} / \mathrm{s})$, $\mathrm{k}_{\mathrm{bu}}$ is the vertical permeability of the upstream blanket $(\mathrm{m} / \mathrm{s}), Z_{\mathrm{bu}}(\mathrm{m})$ is the thickness of the upstream blanket.

$\mathrm{L}_{2}=$ length of impervious core or levee base (m)

$\mathrm{L}_{3}=\sqrt{\frac{k_{f}}{k_{b d}} Z_{b d} d}$

where $k_{b d}$ is the vertical permeability of the downstream blanket $(\mathrm{m} / \mathrm{s})$.

The uplift appearance probabilities are then defined in function of Fh ranges. The greater is Fh the smaller is appearance probability. If there is no impervious layer at levee foundation, the uplift appearance probability is null.

\begin{tabular}{|c|c|c|c|c|}
\hline \multicolumn{5}{|c|}{ Uplift appearance probability function of Fh ranges } \\
\hline \multirow{6}{*}{$\mathrm{Fh}$} & \multicolumn{3}{|c|}{$\begin{array}{c}\text { no silt OR no alluvial materials } \\
\text { OR no water }\end{array}$} & 0 \\
\hline & 0.00001 & $\mathrm{Fh}<$ & 1.1 & 0.8 \\
\hline & 1.1 & $<\mathrm{Fh}<$ & 1.3 & 0.3 \\
\hline & 1.3 & $<\mathrm{Fh}<$ & 1.5 & 0.1 \\
\hline & 1.5 & $<\mathrm{Fh}<$ & 2 & 0.01 \\
\hline & 2 & $<\mathrm{Fh}$ & & 0.001 \\
\hline
\end{tabular}

Figure 14. Uplift appearance probabilities function of ranges of factor of safety (after Durand E. 2015).

Uplift mechanism doesn't lead to breach by itself. When uplift occurs, levee deterioration and cracks in foundation lead to internal erosion in pervious aquifer. The uplift breach probability is then conducted as an internal erosion mechanism with Bligh ratio calculation (without reduction coefficients used for internal erosion).

\section{CARDIGUES TOOL FUNCTIONALITIES}

\subsection{Levee cross-section report}

CARDigues has a simplified visualization tool to create levee cross section report (Fig. 15). For each hydraulic situation considered and for each failure mode, all probabilities related to the cross-section are edited (appearance probability, breach probability and hazard). Global hazard for each flood event and annual hazards for each failure mode are also given. The grey shade hazard classification of the model is also reminded and probabilities are colored in consequences. A simplified scheme is also provided with topographic information, hydraulic levels and disorders (such as trees, burrows, reinforcements, crossing pipes...).

\subsection{Analysis tab}

An analysis sheet will keep the information for each main and chosen modeling what allows users to compare each result by varying one or more settings.

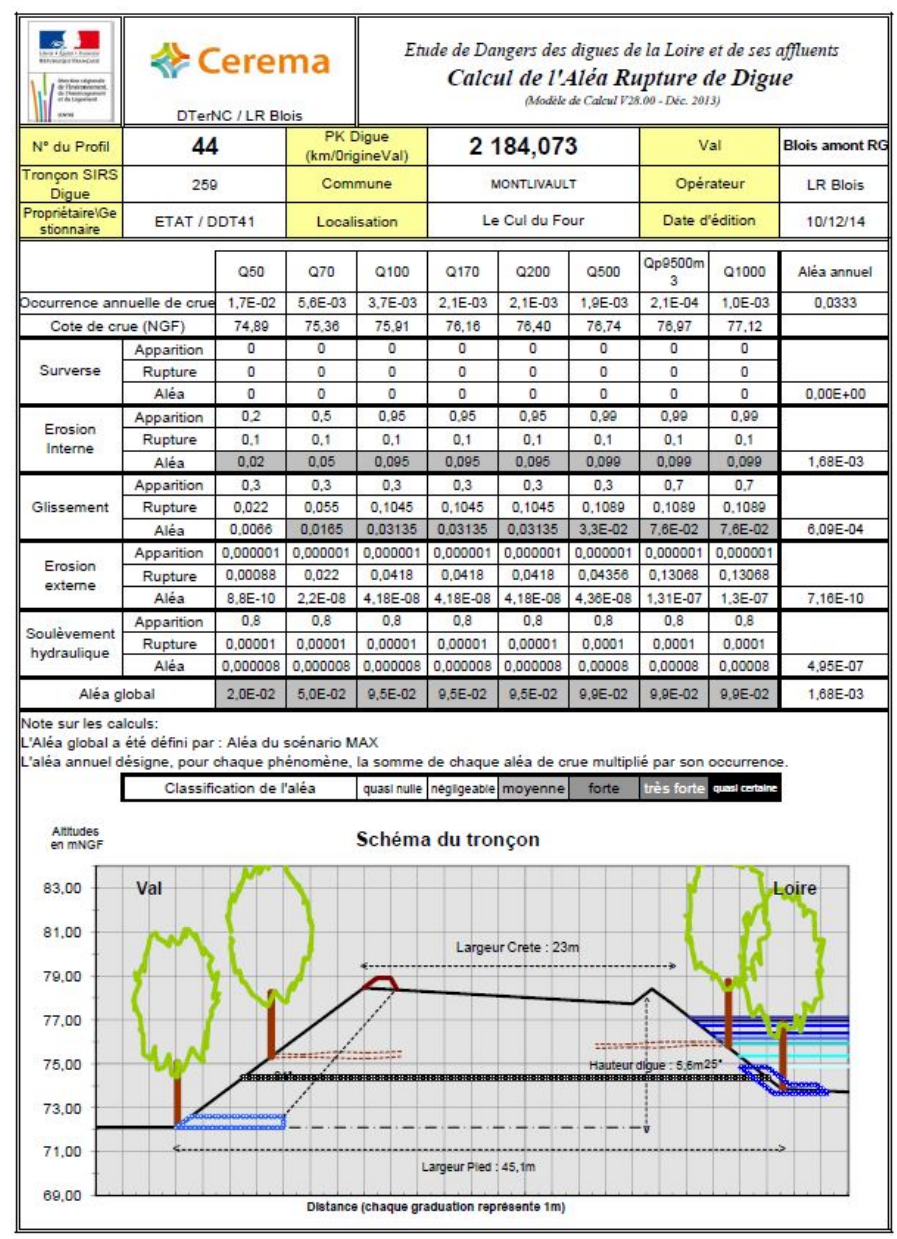

Figure 15. Example of a levee cross-section report edited with CARDigues tool (after Cerema 2015). 


\subsection{Data exportation tab}

An exportation sheet enables users to gather main information of different calculation tabs required to edit the results using a GIS software.

\subsection{GIS presentation of CARDigues results}

Combination of exportation data in a GIS tool enables to established results visualization maps. An example is shown on the figure 16 where probabilities of each failure mode are sets all along the levee system for each cross section. This kind of maps can be elaborate for each failure mode or each flooding event etc.

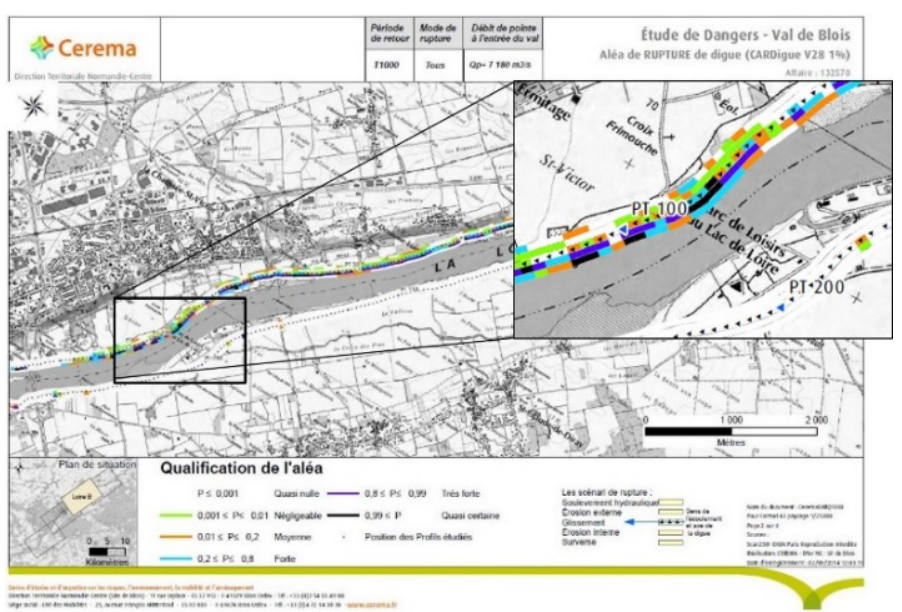

Figure 16. Example of GIS visualization of CARDigues probabilities for the Loire flood T1000 on Blois levees (after Cerema 2015).

\section{CONCLUSION}

Methodology and CARDigues tool is an innovating tool to realized hazard studies on river Loire levees or to make diagnosis on levee systems. It had been used since 2008 on more than 40 hazard studies and amelioration has been done in 2013 in a new version (V28.00). Nevertheless, other ameliorations could be added in a new version such as:

- improvement of automatic procedure to import data from existing levee databases

- possibility to create new failure scenarios;

- possibility to modify geotechnical parameters of levee core material;

- feasibility of coupling CARDigues with a slope sliding tools to improve slope sliding calculations;

- improve internal erosion parameters that are currently too dependent of crossing pipes.

\section{ACKNOWLEDGMENTS}

We greatly thank all persons that have actively contributed to put in place the Loire levees and its tributaries hazard study methodology.

\section{REFERENCES}

Cemagref, 2001. Guide pratique à l'usage des propriétaires et gestionnaires - Surveillance, entretien et diagnostic des digues de protection contre les inondations

Cerema, 2015. Blois class B and C levees hazard studies. Cerema report $\mathrm{n}^{\circ} \mathrm{C} 14 \mathrm{RB} 0060$, may 2015

Durand, E. 2012 Class A Loire river levees hazard studies. CARDigues methodology report $\left(\mathrm{n}^{\circ} 125900\right)$

Durand, E. 2015. Blois class B and C levees hazard studies: failure mode model. Symplifyed fault-trees and CARDigues V28.00 methodology. Cerema report ${ }^{\circ} \mathrm{C} 14 \mathrm{RB} 0060$

ILH, 2013. International Levee Handbook (Ciria, C731, 2013).

Maurin, J. 2011. Calcul des digues à l'érosion interne pour un hydrogramme de crue donnée

Maurin, J. et al. 2013. Loire river levees hazard studies : failure modes model. Digues maritimes et fluviales de lutte contre les inondations. $2^{\text {ème }}$ Colloque national-Digues2013, Hermes, 2013 Lavoisier, Paris

Piney, S. 2011. Retour d'expérience des brèches historiques du val d'Orléans

U.S. Army Corps of Engineers, 1986 (EM 1110-2-1901). Engineering and design: seepage analysis and control for dam. 